\title{
Higher Agricultural Education, Research and Technology
}

\author{
Bipin BM* and Kibebew Kibret \\ School of Natural Resources Management \& Environmental Sciences, Haramaya University, Ethiopia
}

Submission: September 01, 2017; Published: September 18, 2017

"Corresponding author: Bipin BM, School of Natural Resources Management \& Environmental Sciences, Haramaya University, P 0 Box 138, Dire Dawa, Ethiopia, Email: bbmsoil@rediffmail.com

\begin{abstract}
The present generation is running after competitive economic and luxurious growth, but terminating almost on some conflict as well as warfare. Terrorism is spreading on soil, while urbanization, followed by expanding road and rail infrastructure, is consequently shrinking the agricultural land area. Today's lifestyle and high-tech economic race above the ground is challenging the global sustainability, while underground land comprising of the soil-root-biodiversity-water system suffers from acute threats to soil nutrient shortage and type specific degradation. Besides, rapid population growth has made the shrinking land areas sparse resource followed by acute shortage of employability among youth. Under such changing scenario, education in general and particularly in agriculture needs breakthrough to balance the overall agricultural promotion with subsequent changing modes in agricultural research and technology. Let agriculture be a powerful sector for gross rural happiness as well as employment generation through land use planning in a supply chain process mode. The future agriculture would intend to enormous scope for self business and placement on way to commercialize the approach from point of origin (soil) to point of consumption (market).
\end{abstract}

Keywords: Threats to agriculture; Sustainability; Gross rural happiness; Education; Research; Technology

\section{Introduction}

How to alleviate the poverty from farming communities and how to balance the changing scenario in global stability are the twin issues that need breakthrough in agricultural education, research and technologies. Soil in continuity brings people at common platform through mutual understanding and, as a result, administrative boundaries of nations result into brotherhood. This is possible through agriculture, not at all by warfare. Today some country is threatening neighbouring countries against restoration of brotherhood, humanity, mutual cooperation, peace, harmony, livelihood and happiness. Administrative boundaries are not tagged with land boundaries and so agricultural planning within one boundary may work in other neighbouring nation too. Besides, agriculture has enough scope to mitigate the threats from climate change [1]. Besides, food nutrition is another problem the world is facing. The threats to the soils due to type specific pollution, degradation, contamination, biodiversity loss, soil sickness and partial factor productivity are also emerging. Organic farming and conservation agriculture are two innovative agricultural systems necessitating attention [2].

Agricultural research and technology further need special emphasis in order to ensure demand driven reliable recommendations in various aspects in agriculture. The present paper aims at a conceptual framework to promote the higher education in agriculture and subsequent research options for technology generation in order to re-structure it in terms of productivity, safety, profitability and overall sustainability.

\section{Agricultural Higher Education}

Opportunity is an outcome of necessity as well as creativity. Agricultural education often suffers from stereotypic course curriculum, wherein comprehensive learning is more or less far from the truth. The said learning lacks system approach of knowledge being imparted to students through practical based conceptual trainings and more often suffers from completeness. Medical science relates to repairing and maintenance of human body and restoration of a sound health. Any health problem of a person calls for immediate attention and treatment. That's why medical students rest on proven practical knowledge that makes them more sincere and enthusiastic for learning and training. Engineering students work on aspects like luxury, comfort, energy generation, information tools, travelling, recreation and industry, for which there is tremendous demand and opportunity leading to a deep sense of attraction among 
students for engineering. However, the agriculture being the sole enterprise for nourishment and survival of humans is least cared as a profession. But, why is such ignorance? Where is the missing linkage hidden? Agricultural education suffers truly from lack of completeness of knowledge and it works on a stereotypic framework that is prescribed in differing modes of isolation. So, there is a need to define location specific opportunities for a teaching and learning tool in agriculture and the teachers are solely responsible to shoulder such accomplishment in a class room, college or university as well as in the fields. One of the ultimate goals of agricultural education and research is to move forward towards corporate sectors in such a framework that ensures poverty alleviation in the farming communities through enhancement in productivity, profitability and sustainability [3]. Obviously, one has to link such teaching and learning approach with agri-business and entrepreneurial skills in a big way. Importantly, this requires opportunities that can be enthusiastically injected in the mind of a student and that too by the teacher in a true farming environment, where farmers are the true witness $[4,2]$.

Education is an everlasting means to design a lifestyle that must be healthy, sociable, peace loving and productive on sustainable basis following an assurance of employment, placement or business profession across the globe for livelihood with gross happiness. Education thus functions in a creative mode that needs to be captured with some competitive goal Agricultural higher education is applied in three tiers viz. student, teacher and farmer to work for opportunity in a planned manner to achieve the goals. Higher education aims at accomplishment of five basic components viz. innovating

a. The student's individuality/attitude so that

b. Originality in mindset could be promoted for subsequent enrichment in

c. Creativity, which accelerates the sense of

d. Competitiveness so that a student, in the field of interest, could successfully get

e. Employment and placement [4].

The above five indicators of completion in education do work under assumptions including smart infra-structures and teaching-learning-demonstrating process. Teachers must get empowered on creative expression in the class, laboratory and field. Creativity and employability through practically proven tools promote the student's conceptual understanding. Such tools equally help to promote better grasp of the theoretical concept even and accelerate the power of overall understanding. Creative and innovative ideas must come from individual instead of cascading from elsewhere. The agricultural education deals with topics full of risks and limitations mostly in open and uncontrolled surroundings. So, the emphasis on creative expression in agricultural education must be nurture in write- shop session using the basic digital media skills and so, but under a well knitted umbrella full of opportunities. By and large, it must be location specific in a given "soil-water-climatevegetation-livestock-human continuum”, a complete system controlling the overall supply chain for livelihood under natural set-up. Unfortunately, our efforts in true sense are almost ornamental suffering from approximation and missing linkage. The traditional academic approaches with latest scientific and indigenous knowledge must also be well taken at least in conceptual framework through practical sessions so that the students may get fully exposed to the relevance and practical implication of the topic in a powerful teaching and learning mode. After all, students have to accept the bare truth of wisdom through "seeing-doing-believing mechanisms" and grasping to apply in days to come for "market based agricultural production and development on sustainable basis". This necessitates a target oriented reform in governance of higher agricultural education on strong infrastructure and teaching-learning mechanism [4].

The course curricula must be demand driven and practical oriented with a clear message of sustainable production in all sectors of agriculture, wherein agro-eco system, soil, water, air and seed are the resources that include production inputs like tillage, irrigation, nutrition, health protection and maintenance following the associated technologies for breeding, mutation, mitigation of disastrous consequences like climate change and drought, soil fertility management, plant protection and processing of harvested produces. Importantly, each course session in different disciplines must convey a powerful message towards overall goal that links the rural markets through production process, demand oriented, supply assured and profit anticipated. Such trainings would surely empower students towards positive opportunities for placement, employment, self agri-business and entrepreneurial skills. Land economics may be appreciated wherein land use planning would be targeted following the supply chain processes for maximum profit [3].

\section{Agricultural Research}

Research is searching for explanation of event, phenomenon, relationship and causes. The simple definition of any scientific research is to perform a methodical study in order to establish and prove a hypothesis or answer for a specific but relevant question. Such answer would be the central goal of an experiment. The research must be systematic following a set of steps. Agriculture does work almost in open system and so it is full of risk, fear, uncertainties, doubts and limitations. Management strategies for agricultural production must be based on a reliable skill of input integration through step by step evaluation of resources involved. Soil, for example, is a basic resource contributing as the foundation to sustainable production and its evaluation for actual as well as potential productivity must be undertaken well before suitability identification of land use choice. Research priority in agriculture is virtually a mandatory following some publication, but the research outcome and recommendation 
in most cases are seldom reliable. Such bitter situations in many cases have made the research environment uncertain in agriculture. In some instances, research problems being proposed and identified are not truly researchable, even though students are carrying out such research works mainly to fulfill the requirement of a degree without learning much about tips and methodology of conducting a research. As stated by Leedy \& Ormrod [5], research is defined as the systematic process of collecting and analyzing information (data) in order to increase our understanding of the phenomenon about which we are concerned or interested. This is a process of steps used to collect and analyze information in order to increase our understanding of a topic or issue [6].

\section{Agricultural Technology}

Technology is simply the assemblage of scientific laws and principles in the form of a tool or device or machine to perform the pre-targeted objectives or goal. So, the technology works in a system that is developed within a set of inputs or components or may be interacting set of sub-systems too in order to yield or generate outputs of interest. These systems consist of subsystems having some set of components that work together to achieve a well defined common goal. The feedback that includes specific information, indication or signal or measure that indicates how well the goal is being achieved, or how well the process is working may be the critical bearing in successful operation of the technology (Figure 1).

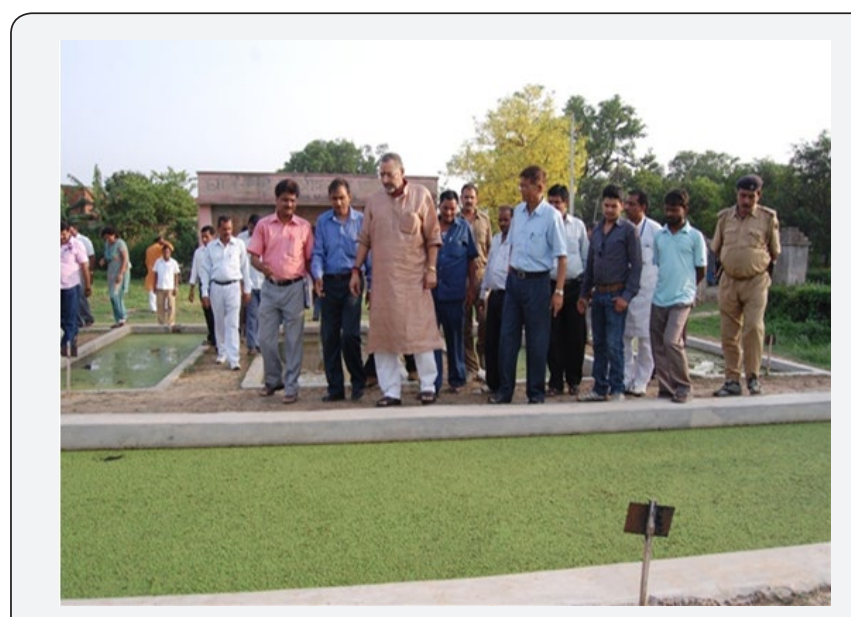

Figure 1: Azolla production technology, Bihar Agricultural University, Sabour, India.

Science is the key to a natural system to disclose its mystery and that too for the welfare of mankind, whereas technology is the extension of such scientific wisdom or capability in order to satisfy our needs through process or tools or device or machine in day to day life within a well defined system surrounded by sub-systems and supra-system, often forming a hierarchy. System to cool room in summer needs fan or cooler or air conditioning device. System to construct house and bridge needs multiple set of inputs, journey from Ethiopia to India needs aeroplane, production of food through agriculture from farmland to threshing floor needs system approach, processing, agribusiness management and marketing, entertainment with radio, television, musical devices all need system within the boundary of technology. A medical doctor undergoes for operation of a patient within a system. May be agri-business or soft-ware professionals or production factories, all follow specific system and, thus, they all fall under the realm of technology. Unfortunately, in national policy terms, technology includes only certain specific profession, wherein agriculture as a whole is not within the policy boundary of technology in many countries including Ethiopia. This needs to be amended with further refinement that agriculture is the economic foundation that sustain the national development in whatever sectors including corporatization are flourishing. But, to sustain agriculture, it is first priority to look for a prime land that rests on soil and its health, because a healthy soil can only build a healthy nation for internal security and gross happiness $[7,8]$.

Students may synthesize the system that makes agriculture viable in order to define an opportunity to work. Can we define indicators of healthy food qualities that could reflect quick impact on human body? We lack symptomatic criteria to be observed quickly on body as a result of consuming the substandard or adulterated or polluted foodstuff. Currently, the available reports indicate that the food materials are often genetically altered, pulses are mixed, spices are polluted, milk and ghee are impure, vegetables are toxic, tea and coffee are adulterated and remaining foodstuffs are made toxic in some way or the other. We have to design and compose some clear-cut "symptomatic yardsticks on body" that will quickly indicate the ill-effects of the foodstuff consumed. Similarly, soil and water qualities need to be well understood in line with their vital impacts on agricultural production. Soil borne diseases as well as fluorine and arsenic problems are seriously emerging. Partial factor productivity causing decline in crop yield is virtually a soil based issue, but we hardly recommend for evaluation of whole soil or pedon. The breeding programme for crop improvement seldom considers soil, water and environment-friendly yardstick as the critical tools. Entomology and pathology do work mostly in isolation without caring for soil types and underground water quality. The earth surface is receiving almost $95 \%$ of incoming solar radiation, but we are not much aware of their role in agriculture except for bringing change in thermal regime and so. Photopedogenesis as a new chapter in soil science $[9,10]$ is a beginning to understand such radiation related interaction issues. Flood with excess water beyond the capacity of a river is virtually a natural resource particularly for agricultural production and calls for a proven management strategy through integrated input set-up and tools [8]. These are some of issues that may form the opportunities in shaping the agricultural education and research.

Thus, each chapter in teaching process must include a well defined opportunity that can empower the students to be 
enthusiastic in learning process. Micro-teaching may help to provide such positive feedback in defining an opportunity of relevance based on prescribed course. But, all such perceptions suffer rudely from unplanned policies mostly structured in isolation. Agriculture in some countries like India and Ethiopia is not treated as technical education, though research and technology development is mandatory in different sectors of agriculture. The agriculture graduates are by and large over frustrated about employment insecurity, very low salary structures, poor social recognition and very low coverage in media. The cumulative effect of such imbalanced policies results into very poor attraction towards this profession and as such, opportunities in agricultural education is at risk and deserves quick attention. For healthy and sustainable agricultural growth, agriculture education must be given well proven priority accepting its standard as a complete technology. These are some of bottlenecks on way to create opportunities in agriculture through teaching and learning.

A medical student normally gets satisfied of running his medical practice just after successful completion of his medical degree. Similarly the agricultural graduates should be well equipped with a strong mindset to get them ready for self employment after completion of their degree. This is a way towards revolutionary transformation in student's mindset for professional satisfaction, where they will feel crazy to accept this profession in agriculture through learning and training. However, such simple proposal needs to have a strong support of government commitment. The agriculture higher education and research will thus begin to move in quantized spirit in order to achieve the mission. The student with entrepreneurial mindset may add value to his business at every level making his creativity expanded towards competitiveness, which may enable his profession/business running faster. A student through education and research after obtaining a degree may look for his future in some of the following fields of agri-business or entrepreneurship/skills:

a. Soil evaluation for fixing the potential soil productivity.

b. Soil suitability for land use choice for the most remunerative return.

c. Soil laboratory for preparing soil health card and water quality.

d. Soil/clay for detoxification of toxins in human stomach.

e. Soil as the direct food, medical treatment, medicine using type specific clays.

f. Soil as raw materials for crockery, brick making etc.

g. Tissue culture \& Soil Biotechnology.

h. Breeding in crops, vegetables, spices and fruits.

i. Plant Patho-lab for plant protection measure chart. j. $\quad$ Food processing and packaging.

k. Preservation of fruits and vegetables.

l. Seed processing, storing and preservation.

m. Growing and marketing of vegetable, fruit and flower seedlings/nurseries.

n. Recycling of crop residues, solid and liquid waste materials, vermin-compost.

o. Conservation agriculture vs. evergreen agriculture.

p. Organic farming vs. integrated farming system.

q. Different systems in value addition in agriculture.

Besides, application of electricity, magnetism, monochromatic light and sound can stimulate the growth of plants. However, specific technologies are yet to discover not only to improve the yield and quality, but also to protect crop from disease, insect pest and frost and reduce the requirements for fertilizers and pesticides. Such "Electro-culture" needs to be encouraged in a big way. Besides, human population today is suffering from collapsible situation caused by adulteration, toxicity; pollution and quality deterioration of not only the foodstuff, but both water and air even. The protective medical treatments start with soil and end with grain, flesh and milk. The entrepreneurial skills must be cohesive to similar vision, mission and goal. (Table 1) is merely an example to begin how to advance our skill towards agri-business following the expected challenges/opportunities, whereas (Table 2) stresses on comparative visibility of agriculture with medical science and engineering $[7,8]$.

Table 1: Proposed solution to overcome challenges through agribusiness.

\begin{tabular}{|c|c|}
\hline Challenges/Opportunities & Solution/Agri-business \\
\hline Pulses are mixed/adulterated & To maintain the purity of variety \\
\hline Oils are impure/adulterated & To maintain quality/purity \\
\hline $\begin{array}{l}\text { Rice and wheat are toxic with } \\
\text { arsenic }\end{array}$ & $\begin{array}{c}\text { To get/grow toxic free crop } \\
\text { grains }\end{array}$ \\
\hline Scented rice becoming abandon & To establish the scented strain \\
\hline $\begin{array}{l}\text { Spices are almost duplicate/ } \\
\text { adulterated }\end{array}$ & To restore the purity \\
\hline $\begin{array}{l}\text { Milk and milk products are } \\
\text { adulterated }\end{array}$ & To maintain quality/purity \\
\hline Small millets are disappearing & $\begin{array}{l}\text { To restore and promote their } \\
\text { production }\end{array}$ \\
\hline Road map of agriculture & $\begin{array}{l}\text { To begin with soil evaluation/ } \\
\text { land use suitability }\end{array}$ \\
\hline Low price vegetables/fruits & $\begin{array}{l}\text { To add values by processing/ } \\
\text { preservation }\end{array}$ \\
\hline Mushroom/honey bee & To maintain quality \\
\hline Medicinal plants/soil & $\begin{array}{c}\text { To standardize for medicinal } \\
\text { values }\end{array}$ \\
\hline
\end{tabular}


Table 2: Comparative visibility of agriculture with medical science and engineering.

\begin{tabular}{|c|c|c|c|}
\hline $\begin{array}{c}\text { Distinguishing } \\
\text { Traits }\end{array}$ & Agriculture & $\begin{array}{l}\text { Medical } \\
\text { Science }\end{array}$ & Engineering \\
\hline Origin/genesis & Close to nature & $\begin{array}{l}\text { Synthetic and } \\
\text { artificial }\end{array}$ & Artificial \\
\hline $\begin{array}{l}\text { Importance } \\
\text { and use }\end{array}$ & $\begin{array}{l}\text { Nourishment and } \\
\text { survival of life }\end{array}$ & $\begin{array}{l}\text { Maintenance } \\
\text { and repairing } \\
\text { for life }\end{array}$ & $\begin{array}{c}\text { Comfort/ } \\
\text { luxury and } \\
\text { energy } \\
\text { support to life }\end{array}$ \\
\hline $\begin{array}{l}\text { In case of } \\
\text { failure }\end{array}$ & $\begin{array}{l}\text { Existence of life } \\
\text { ends }\end{array}$ & $\begin{array}{l}\text { Sick person at } \\
\text { risk or die }\end{array}$ & $\begin{array}{l}\text { Life style may } \\
\text { be hard and } \\
\text { uncomfortable }\end{array}$ \\
\hline Alternative & $\begin{array}{l}\text { It cannot be } \\
\text { substituted }\end{array}$ & $\begin{array}{l}\text { Medicinal } \\
\text { plants and } \\
\text { even soil in } \\
\text { some cases }\end{array}$ & $\begin{array}{c}\text { Indigenous } \\
\text { and traditional } \\
\text { means }\end{array}$ \\
\hline Education & $\begin{array}{l}\text { Student-teacher- } \\
\text { farmer }\end{array}$ & $\begin{array}{l}\text { Student- } \\
\text { teacher- } \\
\text { patient }\end{array}$ & $\begin{array}{l}\text { Student- } \\
\text { teacher- } \\
\text { industry }\end{array}$ \\
\hline Academic goal & $\begin{array}{l}\text { Farming as } \\
\text { self business- } \\
\text { entrepreneur- } \\
\text { employment }\end{array}$ & $\begin{array}{c}\text { Medical } \\
\text { practice- } \\
\text { private clinic- } \\
\text { employment }\end{array}$ & $\begin{array}{l}\text { Corporate } \\
\text { sector, self } \\
\text { industry- } \\
\text { employment }\end{array}$ \\
\hline $\begin{array}{l}\text { Bottleneck in } \\
\text { profession }\end{array}$ & $\begin{array}{c}\text { Lack of } \\
\text { confidence } \\
\text { in farming } \\
\text { practice and } \\
\text { entrepreneurship }\end{array}$ & $\begin{array}{l}\text { Almost } \\
\text { nil due to } \\
\text { professional } \\
\text { satisfaction }\end{array}$ & $\begin{array}{l}\text { Only in some } \\
\text { cases due to } \\
\text { shortage of } \\
\text { placement }\end{array}$ \\
\hline $\begin{array}{l}\text { Promoting } \\
\text { professional } \\
\text { confidence } \\
\text { by teaching- } \\
\text { learning- } \\
\text { research }\end{array}$ & $\begin{array}{l}\text { Special measure } \\
\text { by government/ } \\
\text { university/ } \\
\text { institutions to } \\
\text { attain } 100 \% \\
\text { professional } \\
\text { satisfaction }\end{array}$ & $\begin{array}{l}\text { Almost in full } \\
\text { satisfaction }\end{array}$ & $\begin{array}{l}\text { Continuous } \\
\text { promotion }\end{array}$ \\
\hline $\begin{array}{l}\text { Choice/option } \\
\text { of student for } \\
\text { admission }\end{array}$ & $\begin{array}{l}\text { Virtually no } \\
\text { option/choice } \\
\text { for admission in } \\
\text { agriculture and } \\
\text { accepts as last } \\
\text { option }\end{array}$ & $\begin{array}{c}\text { First option } \\
\text { for students of } \\
\text { Biology group }\end{array}$ & $\begin{array}{l}\text { First option } \\
\text { for Math. } \\
\text { group }\end{array}$ \\
\hline $\begin{array}{l}\text { Road map of } \\
\text { agriculture }\end{array}$ & $\begin{array}{l}\text { Parametric/ } \\
\text { quantitative soil } \\
\text { based strategic } \\
\text { planning being } \\
\text { foundation in } \\
\text { agricultural } \\
\text { revolution }\end{array}$ & $\begin{array}{c}\text { Integration } \\
\text { with soil, clay } \\
\text { and medicinal } \\
\text { plants }\end{array}$ & $\begin{array}{c}\text { Mechanization } \\
\text { and } \\
\text { processing } \\
\text { tools }\end{array}$ \\
\hline $\begin{array}{l}\text { What needs } \\
\text { to be done } \\
\text { to make } \\
\text { agriculture } \\
\text { more } \\
\text { profitable? }\end{array}$ & $\begin{array}{l}\text { Reliable and well } \\
\text { proven approach } \\
\text { towards } \\
\text { productivity, } \\
\text { profitability and } \\
\text { sustainability } \\
\text { in agriculture } \\
\text { through } \\
\text { education }\end{array}$ & $\begin{array}{c}\text { Linking } \\
\text { medical to } \\
\text { food, water, } \\
\text { soil, clay, } \\
\text { medicinal } \\
\text { and aromatic } \\
\text { plants }\end{array}$ & $\begin{array}{c}\text { Linking } \\
\text { engineering } \\
\text { to agricultural } \\
\text { mechanization } \\
\text { and } \\
\text { processing } \\
\text { options }\end{array}$ \\
\hline
\end{tabular}

\section{Conclusion}

The successful execution of the programme to strengthen the capacity of higher agricultural education, research and technology will ensure food security, poverty reduction and climate change adaptation besides fostering Inter-institutional linkages, networking and academic partnerships. A systematic approach on way to commercialize the agricultural production following the effective land use planning would ensure opportunities for employment of the youth in a big way.

\section{References}

1. Mishra BB, Richa Roy (2014) Global Climate Change: Myth, Reality and Mitigation. In: Choudhary ML et al. (Eds.), Climate Dynamics in Horticultural Science. Vol II Apple Academic Press Inc., Canada, pp. 126-139.

2. Mishra BB (2015a) Soil Science and Land Use Planning: Myth, Reality, Evidence and Challenge. EC Agriculture 1(3): 140-148.

3. Mishra BB (2017) Land Economics vs. Land Use Planning. Agri Res \& Tech: Open Access J 10(4): ARTOAJ.MS.ID.555791.

4. Mishra BB (20 14) Promoting productivity in agriculture through $R$ and D vs. Poverty alleviation. Business in Agriculture, Ethiopia, pp. 31-35.

5. Leedy PD, Ormond JE (2005) Practical research: Planning and design. $\left(8^{\text {th }}\right.$ edn), Upper Saddle, USA.

6. Creswell JW (2005) Educational research: Planning, conducting, and evaluating quantitative and qualitative research. In: Pearson NJ (Eds.), Upper Saddle River. ( $\left.2^{\text {nd }} e d n\right)$, USA.

7. Mishra BB (2015b) Make in India and that too for Indian Agriculture. Business in India, pp. 34-38.

8. Mishra BB (2015c) Make in India for Agriculture vs. Corporatization. EC Agriculture, UK, pp. 520-529.

9. Mishra BB (1996) Theory of photopedology. Journal of Indian Society of Soil Science 44(3): 541-543.

10. Mishra BB, Gebrekidan H, Beyene S (2006) Photopedogenesis: Concept and application. Journal of Food, Agriculture and Environment 4(2): 12-14. 
Your next submission with Juniper Publishers will reach you the below assets

- Quality Editorial service

- Swift Peer Review

- Reprints availability

- E-prints Service

- Manuscript Podcast for convenient understanding

- Global attainment for your research

- Manuscript accessibility in different formats

( Pdf, E-pub, Full Text, Audio)

- Unceasing customer service

Track the below URL for one-step submission https://juniperpublishers.com/online-submission.php 